\title{
Sediment provenance during Alpine orogeny: fluid inclusions and stable isotopes on quartz-calcite veins from detritic pebbles
}

\author{
Anne-Sabine Grosjean ${ }^{1,2,7}$ - Véronique Gardien ${ }^{2}$ Michel Dubois ${ }^{3}$. \\ Philippe Boulvais $^{4} \cdot$ Rossana Martini $^{5} \cdot$ Torsten Vennemann $^{6} \cdot$ Bernard Pittet $^{2}$
}

Received: 20 October 2015 / Accepted: 29 August 2016/Published online: 20 September 2016

(C) Swiss Geological Society 2016

\begin{abstract}
An innovative multidisciplinary approach was used on quartz-calcite veins that crosscut pebbles of several lithologies from the French South Alpine Foreland Basin to discern the source of detrital sediments. Microthermometric results indicate that inclusions contain low to moderate salinity $(0.9-9.8 \mathrm{wt} \%$ eq. $\mathrm{NaCl})$ fluids. Oxygen and carbon isotope compositions of quartz and calcite $\left(\delta^{18} \mathrm{O}\right.$ mean at +24.1 and $+24.7 \%$ respectively $(\mathrm{V}$ $\mathrm{SMOW}$ ) and $\delta^{13} \mathrm{C}$ from -1.1 to $+2.0 \%$ (V-PDB)) are comparable with the composition of their host rocks $\left(\delta^{18} \mathrm{O}\right.$ from +17 to $+24.3 \%$ and $\delta^{13} \mathrm{C}$ from -4 to $+1.4 \%$ ). The calculated $\delta^{18} \mathrm{O}$ and $\delta^{13} \mathrm{C}$ values of the fluid trapped in quartz and calcite range from +9.3 to $+21.9 \%$, and from
\end{abstract}

Editorial Handling: W. Winkler.

Anne-Sabine Grosjean

annesabine.grosjean@gmail.com

1 UMR CNRS 6524 Laboratoire Magmas et Volcans, Université Jean Monnet Saint-Etienne, 23 Rue Dr Paul Michelon, 42023 Saint-Étienne, France

2 UMR CNRS 5276 Laboratoire de Géologie de Lyon, Université Lyon1/ENS Lyon, Campus de la Doua, 2 Rue Raphaël Dubois, 69622 Villeurbanne Cedex, France

3 Laboratoire Génie Civil et GéoEnvironnement, Université Lille 1, EA 4515, 59655 Lille, France

4 UMR CNRS 6118, Observatoire des Sciences de l'Univers de Rennes, Université Rennes 1, 35042 Rennes Cedex, France

5 Section des Sciences de la Terre, Université de Genève, 13 Rue des Maraîchers, 1205 Geneva, Switzerland

6 Institute of Earth Sciences (ISTE) Géopolis 4634, University of Lausanne, 1015 Lausanne, Switzerland

7 Present Address: UMR CNRS 6282 Laboratoire Biogéosciences, Université de Bourgogne, 6 Boulevard Gabriel, 21000 Dijon, France
-2.6 to $+4.1 \%$ respectively. These data suggest isotopic buffering of the fluid by the host rocks. Fluid trapping conditions were $105-185 \mathrm{MPa}$ and $175-310{ }^{\circ} \mathrm{C}$. Using a lithostatic gradient, the conditions of fluid entrapment correspond to a depth of vein formation from 4 to $7 \mathrm{~km}$. Petrographic and geochemical data obtained on the host rocks, their veins and fluid inclusions suggest that the source of the conglomerates is the inner part of the Alps rather than reliefs surrounding the foreland basin. The study of fluid inclusions in veins provides a powerful and innovative approach to link the production of detrital sediments with tectonic events, to trace the provenance of conglomerates and to reconstruct the regional geometry of the drainage system.

Keywords Provenance - Oxygen and carbon isotopes . Water-rock interactions · Oligocene $\cdot$ Western Alps

\section{Introduction}

The study of rock erosion, sediment transport and mass redistribution is a key to unravel climatic and tectonic processes that shape the landscape from mountains to basins. At the periphery of mountain ranges, foreland basins represent large-scale topographic lows progressively filled by the detrital products of previously buried rocks eroded after their exhumation (DeCelles and Giles 1996; Burbank 2002). Petrography, thermochronology and geochemistry of sandstones and conglomerates are classical tools for tracing the source of the synorogenic detritus, sedimented in relation to surface uplift and erosion (e.g. von Eynatten 2003; Najman 2006). Surface uplift is associated with tectonic stress responsible for the development of ductile to brittle deformation zones that are pathways for 
fluids of various origins (metamorphic, magmatic or meteoric; Siebenaller et al. 2012; Marsala et al. 2013). The study of the minerals sealing the veins can provide information on the fluid source and on the $\mathrm{P}-\mathrm{T}$ regime prevailing during tectonic processes (Krenn et al. 2008; Miron et al. 2013). Witnesses of fluids are trapped as fluid inclusions in minerals sealing the veins. The petrographic and microthermometric characteristics of the fluid inclusions together with the isotopic composition $(\mathrm{O}, \mathrm{H}$ and $\mathrm{C})$ of the fluids and their host minerals are commonly used to discern the origin of the fluid types. Fluids of surficial origin (meteoric, groundwater) are conventionally used to reconstruct palaeo-elevation of mountain belts (e.g. Sharp et al. 2005; Gébelin et al. 2013). Fluids of deep origin (metamorphic, magmatic) provide valuable records of the physical and chemical evolution of the rock, as well as the $\mathrm{P}-\mathrm{T}$ conditions related to the conditions of fluid entrapment (e.g. Roedder 1984; Mullis 1994; Siebenaller et al. 2012; Marsala et al. 2013).

Cenozoic detritic succession in the South Alpine Foreland Basin (SAFB) contains pebbles of both magmatic/ metamorphic and sedimentary origins. The provenance of the endogenous rock is known to be from the Internal Alps (e.g. Gubler 1958; Bodelle 1971; Morag et al. 2008; Schwartz et al. 2012) constraining the proximal source of the drainage system. However, the sedimentary rocks may have various sources in the accretionary wedge and in the foreland preventing any clear identification of watershed and river pathways.

In this study, we present data from fluid inclusions (microthermometry, Raman spectroscopy, isotopic composition of the fluids) and their host minerals (microstructures, cathodoluminescence, isotopic composition) in veins from host rocks whose provenance is unclear. We compare our results with lithologies from which the sources in the Western Alps are already constrained (such as basalt, serpentinite and radiolarite pebbles). This innovative approach enables us (1) to trace the catchments and to discern the various possible sources of this detrital material, (2) to reconstruct and discuss the extension of the drainage pathway through the accretionary wedge, and (3) to establish the location of the higher eroded massifs. Information on the types of fluids prevailing during vein formation is also discussed.

\section{Background}

\subsection{Geological setting}

The Western Alps result from the subduction and collision between the European and Apulia-Africa plates since the Late Cretaceous (e.g. Dewey et al. 1973; Rosenbaum and
Lister 2005; Handy et al. 2010). The convergence between the two plates led to the closure of the Tethyan Ocean, to post-collisional crustal horizontal shortening, and to the juxtaposition of the internal and the external zones separated by the Pennine Thrust (Fig. 1; Coward and Dietrich 1989; Schimd and Kissling 2000). The internal zone is made up of the superimposition of metamorphic nappes derived from the inverted ocean and its European and Adriatic margins (de Graciansky et al. 2011), while the external zone consists of the External Crystalline Massifs (Argentera and Pelvoux massifs, Fig. 1) and of the Alpine foreland basin. In southeastern France, the foreland basin consists of a succession of piggy-back basins located at the top of thrust sheets (Siddans 1979; de Graciansky et al. 1989; Ford and Lickorish 2004) that allowed the preservation of the Cenozoic sedimentary rocks in a complex network of palaeovalleys active during Eocene/Oligocene (Grosjean et al. 2012, 2015).

The Eocene-Oligocene succession in the study area, the Barrême Basin (Fig. 1), is represented by detrital sediments of the Clumanc Conglomerates, the St-Lions Conglomerates and the Senez Sandstones (Fig. 2a) accumulated in different depositional environments that were connected in a southward prograding system. From north to south, the depositional system records the progressive filling of the Barrême Basin during a forced regression (Grosjean et al. 2012). The Clumanc and the St-Lions conglomerates and the Senez sandstones contain clasts of sedimentary rocks and radiolarite, serpentinite, basalt and blueschist pebbles from a former accretionary wedge which today corresponds to the internal zones of the Western Alps (Morag et al. 2008; Bernet et al. 2009; Cordey et al. 2012; Schwartz et al. 2012). The regressive system is the consequence of the uplift of the internal nappes (Briançonnais and Piemontais nappes; Fig. 1) and the activation of the Penninic Thrust around 32-30 Ma ago (Ford et al. 2006; Simon-Labric et al. 2009; Dumont et al. 2011; Schwartz et al. 2012). This major tectonic event established a NE-SW-oriented drainage system that transferred the products of erosion from the internal Alpine Chains to the palaeovalleys in the foreland basin (Grosjean et al. 2012, 2015).

\subsection{Location and description of the investigated samples}

The studied pebbles were sampled in the St-Lions Conglomerate Formation in the Barrême Basin (Fig. 2b). This formation is clast-supported in an andesitic sandy matrix, characterized by the absence of cemented fractures (Fig. 2c). The St-Lions Conglomerates have a polymictic composition (magmatic, metamorphic and sedimentary). The less abundant pebbles (25-30\%) are magmatic/ metamorphic clasts from the Internal Alps (Gubler 1958; 


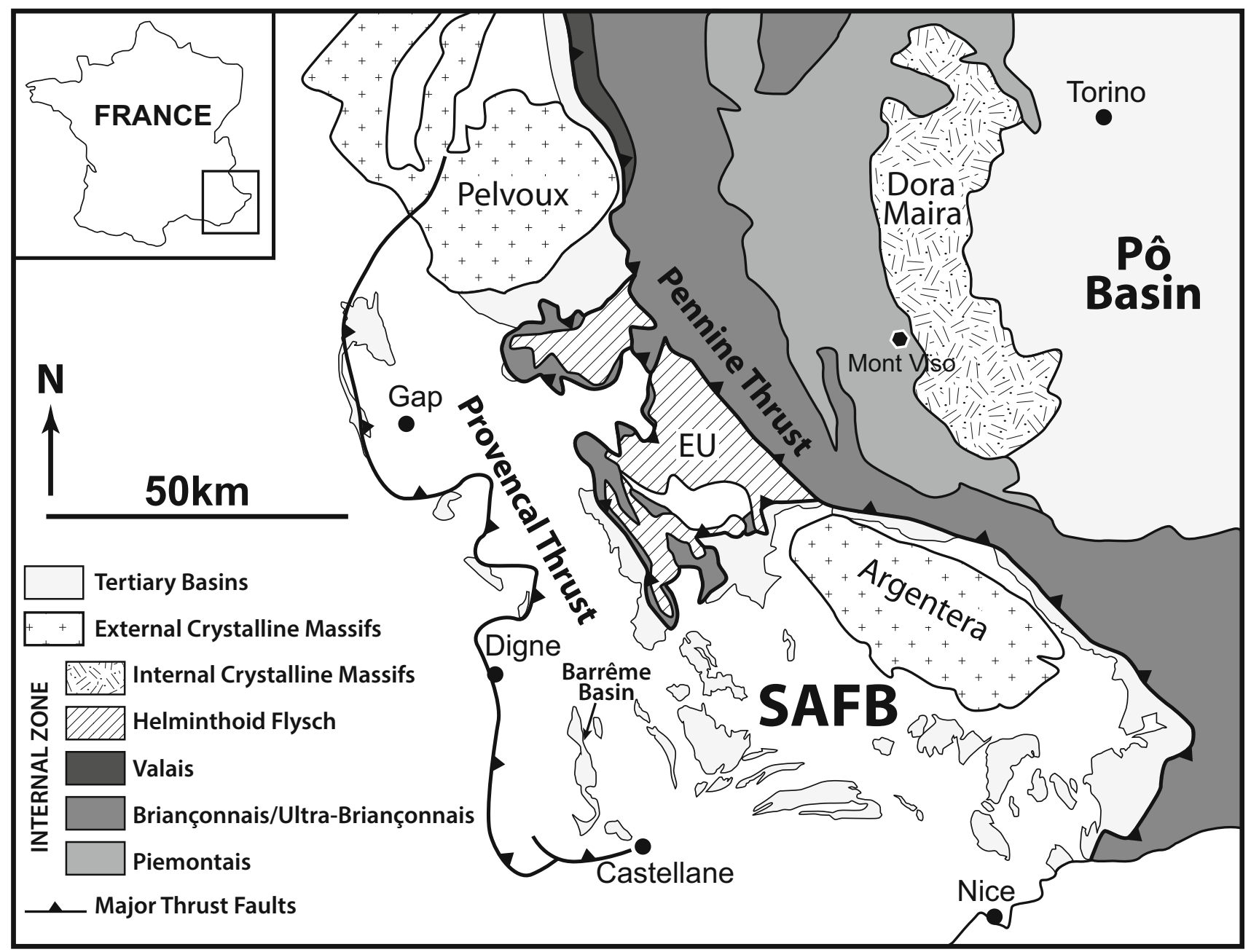

Fig. 1 Geological sketch map of the French Western Alps and the French South Alpine Foreland Basin. The Barrême Basin (studied area) is located in a piggy-back basin on the Provençal Thrust Sheet. EU, Embrun Ubaye nappe; SAFB, South Alpine Foreland Basin

Bodelle 1971; Morag et al. 2008; Schwartz et al. 2012). The dominant pebbles are sedimentary rocks derived either from local reliefs or from unknown localities (Fig. 2d). These undefined sedimentary pebbles-dolomitic rocks as well as some Liassic limestones-have various possible sources as they are exposed in both the Internal Alps and the foreland basin. Given the similarities between the petrography of the sedimentary pebbles and the lithologies surrounding the SAFB, various provenances for the pebbles are possible: (1) Jurassic and Upper Cretaceous limestones from the adjacent topographic highs; (2) the underlying Eocene Nummulitic Limestones; (3) Upper Cretaceous limestones and sandstones from the Castellane platform that was located at about $30 \mathrm{~km}$ to the south of Barrême by erosion of the underlying Argens Conglomerates Formation (Fig. 1); (4) micaceous sandstones which seem to be a facies of the Helminthoid Flysch that represent the cover of the Embrun-Ubaye Nappe (Fig. 1); and (6) Triassic dolomitic limestones and sandstones (Fig. 2e).
Pebbles containing veins have been sampled in each lithology for microscopic observation. Veins containing sufficient amounts of fluid inclusions larger than $5 \mu \mathrm{m}$ were selected for microthermometric and isotopic analyses. The selected samples are: four dolomitic sandstones (samples SL2c, SL2g, SL2h and SL3b), two sandy limestones (samples SL2b and SL2i), and a micaceous sandstone (sample SL5a). We also selected metamorphic and magmatic pebbles: three basalts (samples SL1a, SL1d and SL1e) and one serpentinite (sample SL1b) for comparison with the sedimentary pebbles.

\section{Analytical approaches}

\subsection{Cathodoluminescence}

Cathodoluminescence (CL) was performed at the Department of Earth Sciences, University of Geneva (Switzerland). 

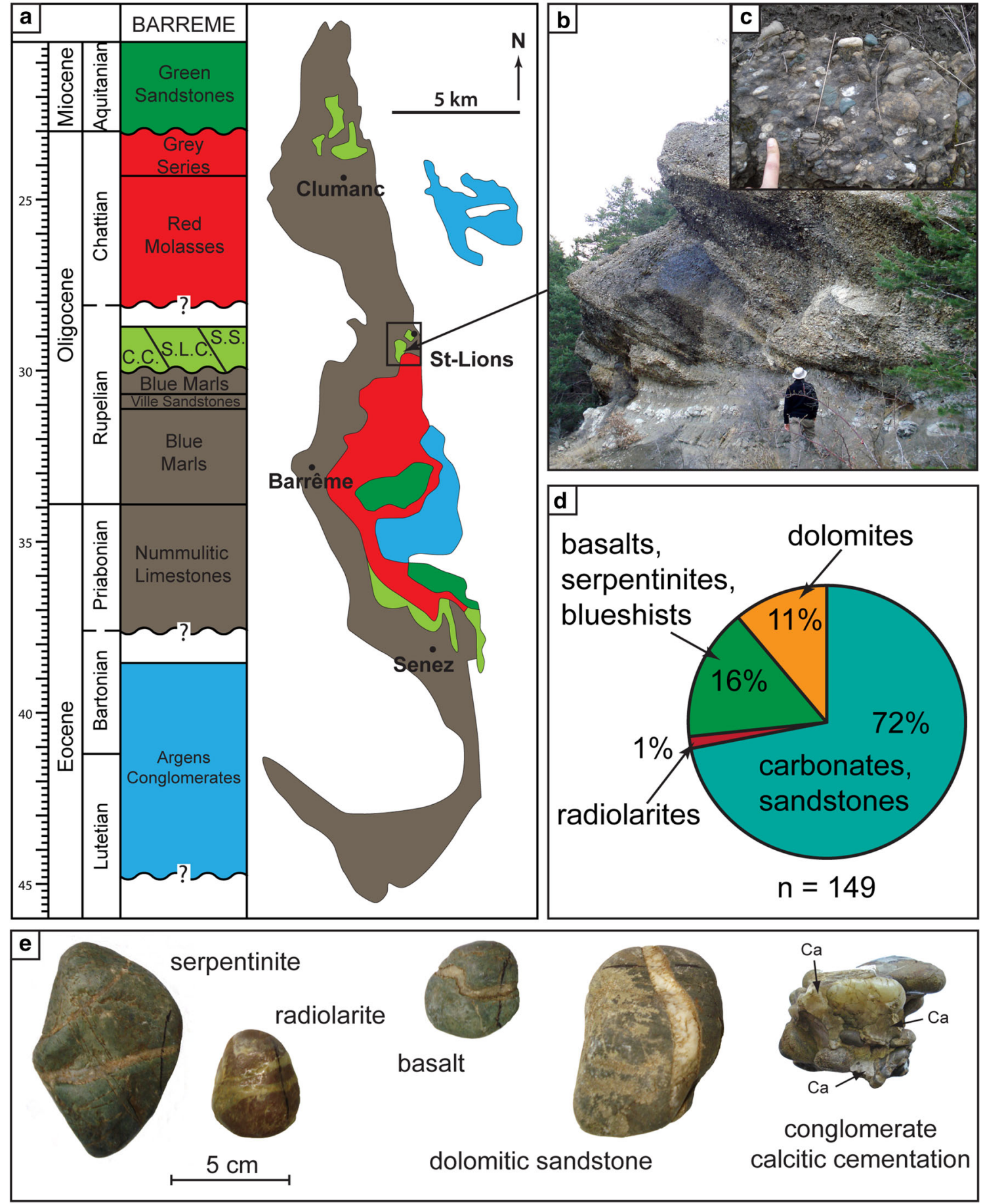

Fig. 2 Sedimentologic and petrographic informations on the sampled pebbles. a Stratigraphic and geographic repartition of the Cenozoic succession in the Barrême Basin. The pebbles were sampled in the StLions Conglomerates that were deposited at about $30 \mathrm{Ma}$ in the northern part of the Barrême Basin. b Photograph of the St-Lions Conglomerates outcrop. c Detail of the matrix-supported polygenic

Eleven polished thin sections were studied using a CITL cold cathode unit (model CL8200 Mk5) operating at 400-450 $\mu \mathrm{A}$ and $14.5 \mathrm{kV}$. Trace elements act as activator elements conglomerates. d Lithological composition of the St-Lions Conglomerates. e Photographs of some lithologies that constituted the pebbles crosscut by quartz-calcite veins and the sampled calcitic cementation that locally replaced the andesitic matrix. Note the size and shape variability of the veins

showing characteristic lines in the CL emission spectrum that allows the identification of growth zones, microcracks and dissolution/recrystallization phenomena. Thus it 
provides complementary information for the reconstruction of the mineral succession precipitated during vein formation.

\subsection{Microthermometry and Raman spectroscopy}

Fluid inclusion microthermometry was performed with a heating-freezing stage Linkam Inc. THM 600 at the Laboratoire de Géologie de Lyon, University of Lyon (France). Calibration was done with synthetic fluid inclusion standards (pure water: ice melting temperature of $0.0^{\circ} \mathrm{C}$ and critical homogenization temperature of $374.1^{\circ} \mathrm{C}$; pure $\mathrm{CO}_{2}-\mathrm{H}_{2} \mathrm{O}$ : $\mathrm{CO}_{2}$ melting temperature of $-56.6^{\circ} \mathrm{C}$; clathrate melting temperature of $10{ }^{\circ} \mathrm{C}$ ). Final ice melting temperature (Tmice) and homogenization temperature (Th) of fluid inclusions were recorded with a precision of \pm 0.1 and $\pm 1{ }^{\circ} \mathrm{C}$ respectively. Tmice measurements permitted to determine the salinity of the fluid (expressed in wt $\%$ eq. $\mathrm{NaCl}$ ) using the revised equation of Bodnar (1993) for a $\mathrm{H}_{2} \mathrm{O}-\mathrm{NaCl}$ chemical system. The determinations of Th allowed the calculation of the isochores (Zhang and Frantz 1987) using standard deviation $(1 \sigma)$ of microthermometric values for each population of each sample. The nature of the fluids trapped in inclusions was obtained through the analysis of each phase (gas and liquid) of individual inclusions in quartz and calcite using a Labram HR800 Raman microspectrometer at the Laboratoire de Géologie de Lyon, ENS Lyon (France) using a $514.5 \mathrm{~nm} \mathrm{Ar}^{+}$laser source of excitation.

\section{$3.3 \delta^{13} \mathrm{C}$ and $\delta^{18} \mathrm{O}$ of the bulk rock}

The carbon and oxygen isotope composition of the host rocks was measured on 2-4 mg of rock powder, at the Stable Isotope Laboratory, University of Lausanne (Switzerland), with a GasBench II connected to a Finnigan MAT DeltaPlus XL mass spectrometer, using a He- carrier gas system according to a method adapted after Spötl and Vennemann (2003). The isotopic ratios were normalized using an in-house Carrara Marble standard calibrated against V-PDB for both carbon and oxygen isotope compositions. V-PDB values were recalculated to the V-SMOW scale for $\delta^{18} \mathrm{O}$ values of carbonates. External reproducibility for the analyses estimated from replicate analyses of the in-house standard $(\mathrm{n}=11)$ is $\pm 0.1 \%$ for both $\delta^{13} \mathrm{C}$ and $\delta^{18} \mathrm{O}$.

\section{$3.4 \delta^{13} \mathrm{C}$ and $\delta^{18} \mathrm{O}$ analyses of host minerals containing fluid inclusions}

The oxygen and carbon isotope analyses of the host minerals were carried out at the Laboratoire Géosciences, University of Rennes 1 (France), using a VG SIRA-10 triple collector mass spectrometer. Analyses were carried out on a powder of previously handpicked quartz grains under a binocular microscope and crushed using boron carbide pestle and mortar. Mineral purity (determined optically) was always higher than $98 \%$. About 6-7 mg of silicate materials were reacted with $\mathrm{BrF}_{5}$ in $\mathrm{Ni}$ tubes at $670{ }^{\circ} \mathrm{C}$ overnight (following the method of Clayton and Mayeda 1963). The liberated $\mathrm{O}_{2}$ was then converted into $\mathrm{CO}_{2}$ by reaction with hot graphite. The oxygen isotope composition is quoted using the $\delta$ notation with respect to V-SMOW. Measured quartz $\delta^{18} \mathrm{O}$ values have been slightly corrected by less than $0.2 \%$ considering the long-term quartz NBS28 standard and the in-lab standard A1113 granite measurements. Analytical precision is estimated to be $\pm 0.2 \%$ for the $\delta^{18} \mathrm{O}$ of quartz. $10-12 \mathrm{mg}$ of calcite powder was reacted with anhydrous $\mathrm{H}_{3} \mathrm{PO}_{4}$ at $50{ }^{\circ} \mathrm{C}$. The oxygen and carbon isotope compositions of the liberated $\mathrm{CO}_{2}$ were analysed on the mass spectrometer and are quoted using the $\delta$ notation with respect to V-SMOW and V-PDB respectively. Analytical precision is estimated to be $\pm 0.15 \%$ o for the $\delta^{18} \mathrm{O}$ and $\pm 0.1 \%$ for the $\delta^{13} \mathrm{C}$ of calcite.

\section{$3.5 \delta^{18} \mathrm{O}, \delta \mathrm{D}$ and $\delta^{13} \mathrm{C}$ of fluid inclusions}

The hydrogen isotope composition of the fluid contained by the inclusions was determined at the Stable Isotope Laboratory of the University of Lausanne (Switzerland). About $1 \mathrm{~g}$ of calcite or quartz grains was placed in a quartz tube, evacuated for several hours and then heated for thermal decrepitation of the fluid inclusions. Microstructural observation shows that all the analysed samples contained two or more fluid inclusion populations. Tests of stepwise heating, allowed selective decrepitation of two populations of fluid inclusions. The temperature of decrepitation obtained for the two populations of fluid inclusions in calcite are 150 and $350^{\circ} \mathrm{C}$ respectively, and 200 and $500{ }^{\circ} \mathrm{C}$ in quartz. All fluid inclusion populations were also extracted in a single heating step. The composition of the bulk fluid inclusion content was compared with the composition of fluids extracted separately from the different populations of inclusions. All volatiles liberated were collected in a liquid $\mathrm{N}_{2}$ cold trap. Using the method of Vennemann and O'Neil (1993), the liquid $\mathrm{N}_{2}$ trap was replaced by an ethanol-liquid $\mathrm{N}_{2}$ slush trap held at $-80{ }^{\circ} \mathrm{C}$ to separate water from $\mathrm{CO}_{2}$ and other gases not retrained at $-80{ }^{\circ} \mathrm{C}$. All purified water fractions were subsequently reduced to hydrogen by reaction with $300 \mathrm{mg}$ of zinc metal at $500{ }^{\circ} \mathrm{C}$ for $15 \mathrm{~min}$ (Friedman 1953; Craig 1961). The $\mathrm{D} / \mathrm{H}$ ratios were measured on a Thermo Finnigan 253 mass spectrometer with internal MOW $(\delta \mathrm{D}=-3.5 \%)$, INH $(\delta \mathrm{D}=-114 \%)$ and LIPE $(\delta \mathrm{D}=-59 \%)$ standards. The results are reported in the $\delta$ notation with respect to V-SMOW. Analytical precision for the hydrogen measurements is $\pm 4 \%$ based on replicate measurements of the samples. 
The isotopic composition of quartz and calcite depends on the isotopic composition of the fluid from which minerals precipitate and the isotopic fractionation between the fluid and the solid for a given temperature. The oxygen isotope composition of the fluid in equilibrium with host minerals was calculated based on the oxygen isotope composition of quartz as well as the oxygen and carbon isotope composition of calcite at the temperature of precipitation of minerals. The mean $\delta^{18} \mathrm{O}$ values of fluid in quartz and calcite were calculated according to the quartzwater (Zheng 1993; Méheut et al. 2007) and the calcitewater (O’Neil et al. 1969; Zheng 1999; Horita 2014) fractionation factors respectively. The $\delta^{13} \mathrm{C}$ values of fluid at equilibrium with calcite were calculated using the equation of Ohmoto and Rye (1979).

\section{Summary of vein and fluid inclusion characteristics}

\subsection{Vein petrography}

Veins are commonly of centimetre scale and filled either by quartz and/or calcite (Fig. 3a) with textures from euhedral geodic (Fig. 3b) to fibrous geometry perpendicular to the wall of the vein (Fig. 3c). Different generations of veins are sometimes superimposed indicating a complex history of fracturing of the host rocks (Fig. 3d), as also revealed by the cathodoluminescence (CL) images indicating overprint of a late calcite within micro-fractures (bright luminescence; Fig. 4). The vein in the basalt displays a palisade of adularia crystals lining the edge of the fracture (Fig. 3e) indicating low-temperature hydrothermal potassic-rich fluids (Browne 1978; Črný and Chapman 1986) possibly resulting from the hydrothermal alteration of the basaltic host rocks. Low-grade metamorphic conditions during fracturing of the rocks are supported by chlorite-epidote assemblage growth in most veins either before or after the quartz and calcite precipitation (Fig. 3f). Some ductile deformation posterior to crystal growth is expressed by wavy extinctions in quartz (Fig. 5a). This deformation locally exhibits irregular grain boundaries (Fig. 5b) due to grain boundary migrations. In mixed quartz-calcite veins, quartz crystals commonly display irregular shapes suggesting a process of dissolution on their edge. The occurrence of calcite between or around quartz suggests that a calcite-saturated fluid percolated in the veins subsequently to the growth of quartz (Fig. 5c). This phenomenon of dissolution-precipitation commonly induces a compositional change and the trapping of new generation of fluid inclusions in marginal growth zones (Folk 1965; Goldstein 2001). In our case, this has been observed in only one sample (SL2g) where the rim of quartz in contact with secondary fractures contain fewer fluid inclusions than the core of the crystal (Fig. 5d).

In order to obtain information about the early conditions of rock fracturing and thus on vein precipitation, only the relative older veins (when various families appeared) were taken into account in this study.

\subsection{Fluid inclusion petrography}

At room temperature, fluid inclusions mostly contain $\mathrm{H}_{2} \mathrm{O}$ liquid, occasionally associated with $\mathrm{CO}_{2}$-dominated vapour, as confirmed by Raman spectrometry. However, $\mathrm{CO}_{2}$ will not be considered in this study due to its low proportion (less than $2.5 \mu \mathrm{mol}$ per gram of studied host mineral). Mono-phase liquid inclusions are scarcely present, also not considered in this study because of their small size and the absence of bubble nucleation after repeated runs.

Microstructural observation of doubly polished thick sections made at room temperature allows the discrimination between two fluid inclusion assemblages (FIA): the "primary fluid inclusions" (FI-1) were trapped during crystal growth and the "secondary fluid inclusions" (FI-2) were formed at any time after mineral growth. Roedder (1984) and Van den Kerkhof and Hein (2001) refer to "pseudosecondary inclusions" that were formed in microcracks during the crystal growth. In this study, these "pseudosecondary inclusions" are included in FI-1 because of their syn-host mineral character.

Primary fluid inclusions occur as isolated (Fig. 6a), clustered or in short trail-bounds formed on the surface imperfection of a crystal during its growth. They are between 5 and $20 \mu \mathrm{m}$ in size (mean at about $10 \mu \mathrm{m}$ ). Secondary fluid inclusions occur in trails (Fig. 6b) in microcracks that intersect the grain boundaries (Fig. 6c). They display irregular shape and are smaller than the primary fluid inclusions with a mean size at $5 \mu \mathrm{m}$.

Textures of post-trapping deformations and pressure/ temperature variations as necking-down (Fig. 6d) are observed in the majority of the studied samples. In order to avoid misinterpretations, the microthermometric measurements have been restricted to fluid inclusions undamaged by deformation and/or reequilibration.

\section{Microthermometric data}

Eleven doubly polished thick sections of calcite and/or quartz veins were prepared for microthermometric analysis. For each sample, final ice melting temperatures (Tmice) and homogenization temperatures (Th) were measured. The dataset obtained on FI-1 and FI-2 in quartz and calcite is represented in Fig. 7. The measured Tmice 

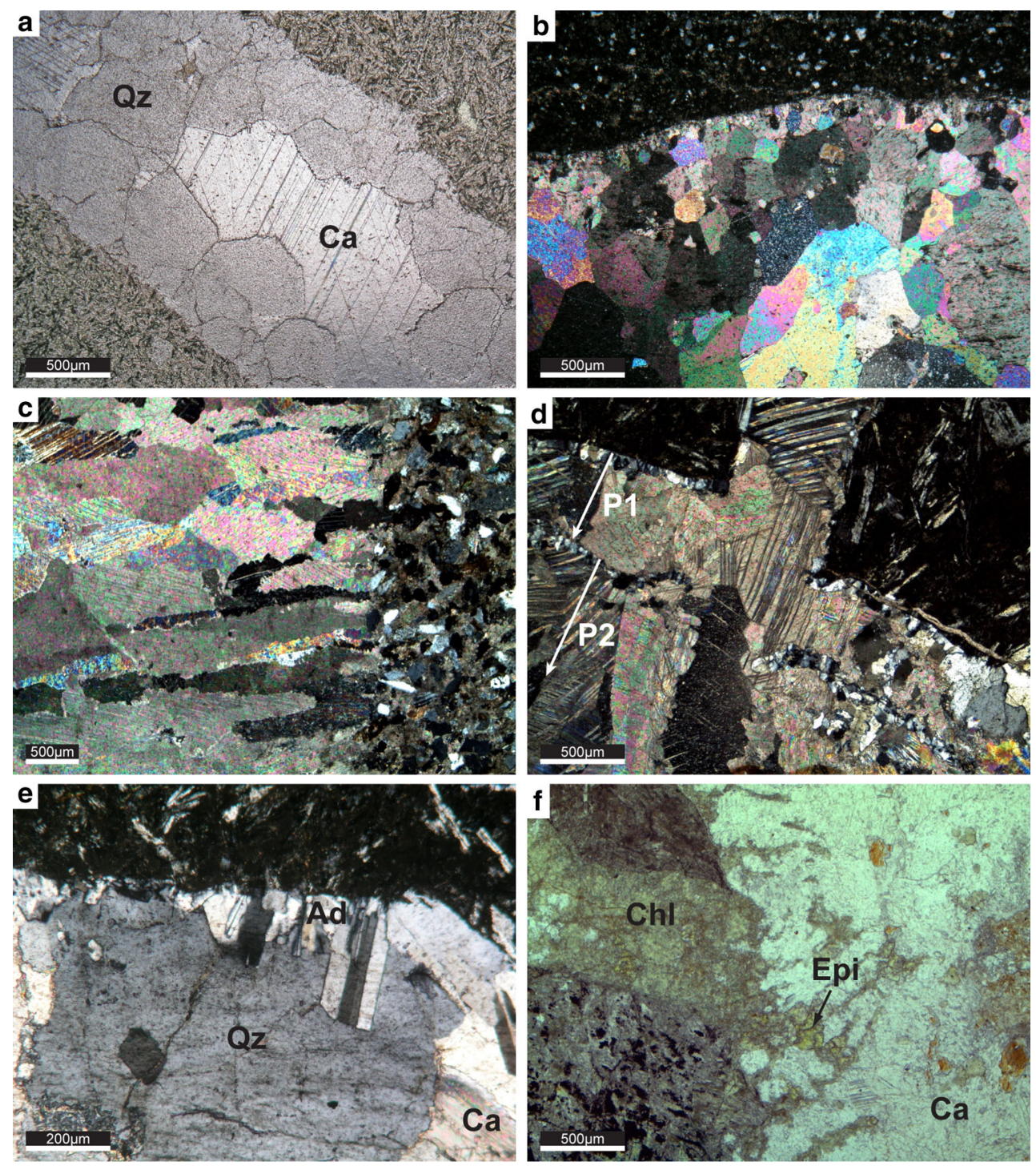

Fig. 3 Microphotographs in transmitted-light illustrating key vein textures. a Typical mixed quartz and calcite vein, here observed in a basalt pebble. Note the crystallization of the quartz $(\mathrm{Qz})$ in the wall and of the calcite $(\mathrm{Ca})$ in the centre suggesting the circulation and precipitation of two successive fluids. b Monomineralic calcitic vein displaying a geodic crystallization. Crossed polarizers. c Monomineralic calcitic vein with a fibrous crystallization perpendicular to the wall of the vein. Crossed polarizers. d Illustration of vein

and Th seem to record a comparable range of values for all the pebbles of different lithologies, and for the different populations of fluid inclusions.

\subsection{Tmice and salinity of fluids}

Tmice range between -6.5 and $-0.5{ }^{\circ} \mathrm{C}$ for fluid inclusions in both quartz and calcite (Fig. 7), indicating a fluid with low to moderate salinity from 0.9 to 9.8 wt\% eq. NaCl. A bimodal distribution of Tmice is observed in two samples (altered basalts): SL1d displays superimposition due to different phases of rock fracturing. Note the multi-opening of this vein illustrated by two phases (P1 and P2) of quartz and calcite crystallization. Crossed polarizers. e Adularia (Ad) crystals growing at the contact to wall-rock and forming a palisade before the crystallization of quartz $(\mathrm{Qz})$ and calcite $(\mathrm{Ca})$. Crossed polarizers. f Mixed vein where chlorite $(\mathrm{Chl})$ and epidote (Epi) minerals are associated to calcite $(\mathrm{Ca})$

temperatures in FI-1 and FI-2 that range between -12.0 to $-7.0{ }^{\circ} \mathrm{C}$ and -6.5 to $1.0{ }^{\circ} \mathrm{C}$, and sample SL1e where temperatures in FI-1 from quartz range between -11.5 to $-4.5{ }^{\circ} \mathrm{C}$ and -3.5 to $1.0^{\circ} \mathrm{C}$ (Fig. 7). The lowest Tmice values correspond to highest fluid salinities (8.5-15.5 wt\% eq. $\mathrm{NaCl}$ ) possibly corresponding to another fluid inclusion population trapped in these samples. However, no correlation has been observed between the location of the fluid inclusions in the host minerals and in the veins with the measured temperatures. 


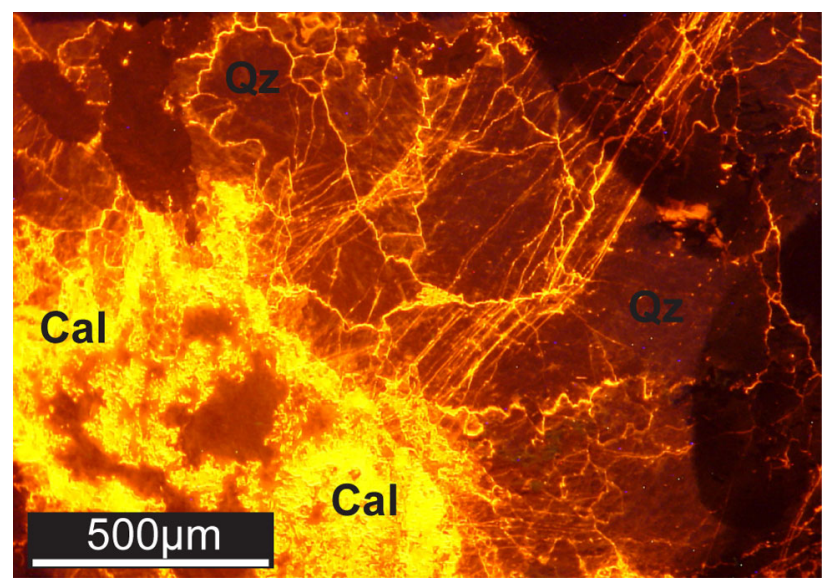

Fig. 4 Cathodoluminescence microphotograph illustrating the late circulation of a calcitic fluid (Cal, bright yellow) in microcracks that intersect the early quartz crystals $(\mathrm{Qz}$, dusky orange $)$

\subsection{Th and P-T conditions of fluid entrapment}

On heating, the fluid inclusions homogenized to the liquid phase. Regardless of lithology, homogenization temperatures range between 120 and $220{ }^{\circ} \mathrm{C}$ (Fig. 7). As no clear difference between the two populations of fluid inclusions can be made, we conclude that identical trapping conditions of fluids have prevailed during the opening and subsequent deformation of veins and no long time between these two events.

Isochores of the fluid inclusions (Fig. 8) were calculated using the equation of Zhang and Frantz (1987). Lanari et al. (2011) estimated a transition of the Alpine geothermal gradient between 50 and $30 \mathrm{Ma}$ from about $10^{\circ} \mathrm{C} / \mathrm{km}$ during subduction to $40{ }^{\circ} \mathrm{C} / \mathrm{km}$ during continental collision. On the basis of the age of St-Lions Conglomerates deposition at about $30 \mathrm{Ma}$, as well as of the low-grade metamorphic minerals (chlorite and epidote assemblages, Fig. 3f) and ductile deformation (wavy extinctions and grain boundary migration in quartz crystals, Fig. 5a, b) observed in veins, we reasonably estimated a mean geothermal gradient during vein formation around $40{ }^{\circ} \mathrm{C} /$ $\mathrm{km}$. Thus, considering a lithostatic gradient (supported by petrographic characteristics and ductile deformation observed in thin sections), we determined the entrapment temperatures between 175 and $310{ }^{\circ} \mathrm{C}$ for a pressure between $105 \mathrm{MPa}$ and $185 \mathrm{MPa}$ (Fig. 8).
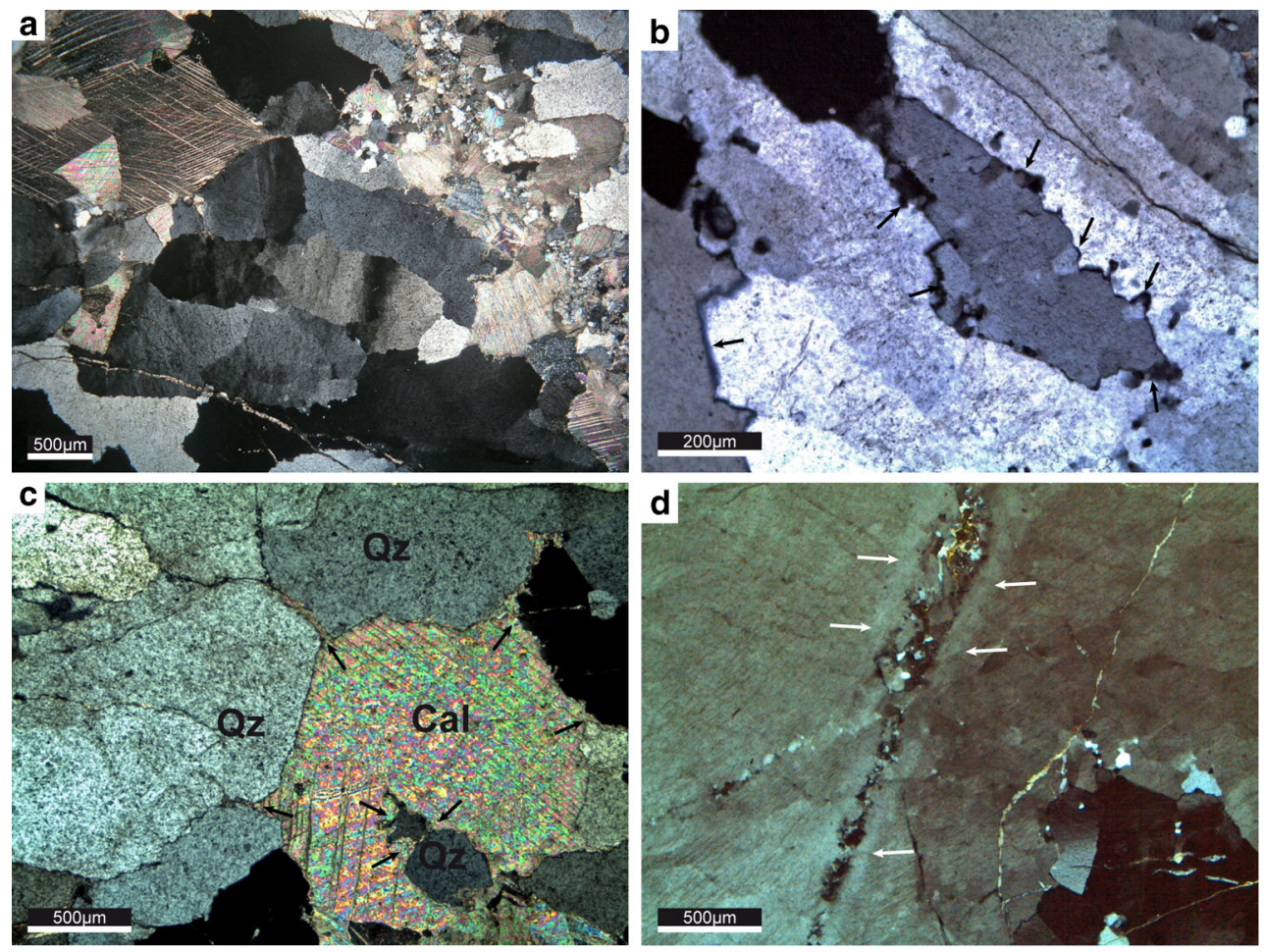

Fig. 5 Microphotographs in transmitted-light (crossed polarizers) illustrating characteristics deformation and dissolution/recrystallization structures observed at the vein and at the mineral scales. a Mixed vein where quartz crystals commonly display wavy extinctions. b Irregular quartz grain boundary migration (black arrows) indicating dislocation phenomena. c Illustration of quartz grain boundary dissolution in contact with calcite. Black arrows underline the quartz irregular shapes and the calcitic-fluid infiltration. $\mathbf{d}$ Late microcracks filled by younger carbonates. At their contact, the walls of quartz display a small amount of fluid inclusions (white arrows) than in its core due to quartz vein opening and fluid flow phenomena 


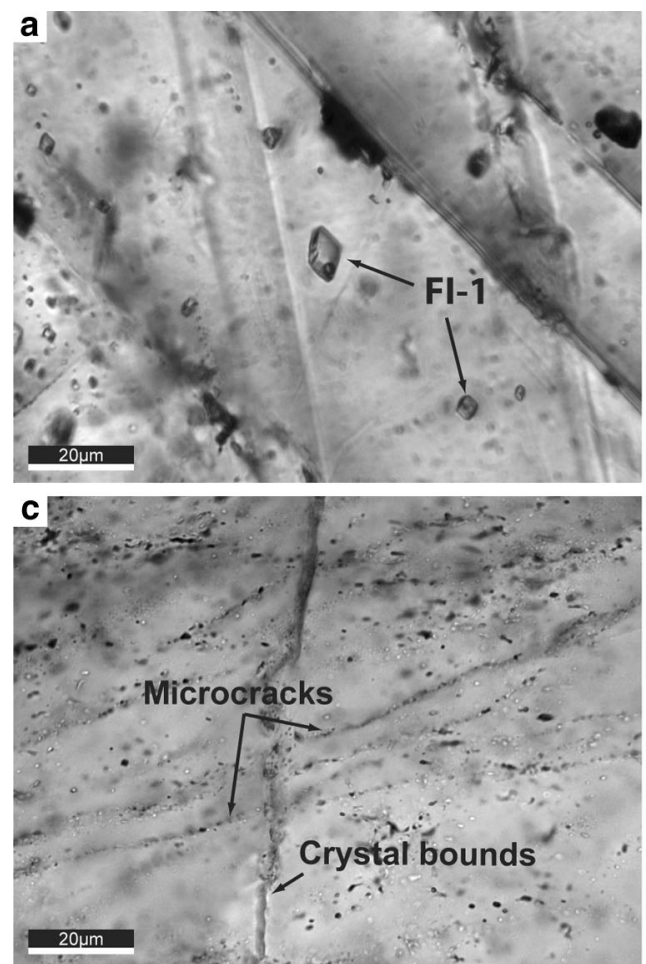

Fig. 6 Microphotographs of thick sections in transmitted-light showing typical fluid inclusions observed in the sampled veins. a Characteristic isolated primary fluid inclusions that present two phases liquid-rich containing $\mathrm{H}_{2} \mathrm{O}-\mathrm{NaCl}+\mathrm{CO}_{2}$. b Secondary two

\section{Stable isotope analyses}

The isotopic values obtained on the whole rocks and on minerals filling veins are presented in Table 1. The isotopic results on the fluid inclusions are given in Table 2.

\subsection{Bulk rock composition $(\mathrm{O}, \mathrm{C})$}

The $\delta^{18} \mathrm{O}$ values of sedimentary rocks pebbles are homogenous and range from +20 to $+24.3 \%$ (Table 1 ), a common composition of sedimentary rocks with a compositional range of +7 to $+38 \%$ (Hoefs 2009). The basalt (sample SL1a) has a $\delta^{18} \mathrm{O}$ value of $+17 \%$ (Table 1) which differs from compositions of unaltered basaltic rocks that have lower $\delta^{18} \mathrm{O}(+6$ to $+10 \%$ for MORB and ocean-island alkali basalt respectively; Kyser 1986; Hoefs 2009). Such ${ }^{18} \mathrm{O}$ enrichment is characteristic of low temperature $\left(<50{ }^{\circ} \mathrm{C}\right)$ interaction between seawater and seafloor basalts (Muehlenbachs and Clayton 1972; Böhlke et al. 1984).

The $\delta^{13} \mathrm{C}$ values obtained on sedimentary rocks (SL2b, SL2g and SL2i) range from -4 to $+1.4 \%$, regardless of the lithology, such values are similar to values of sedimentary Mesozoic carbonates.
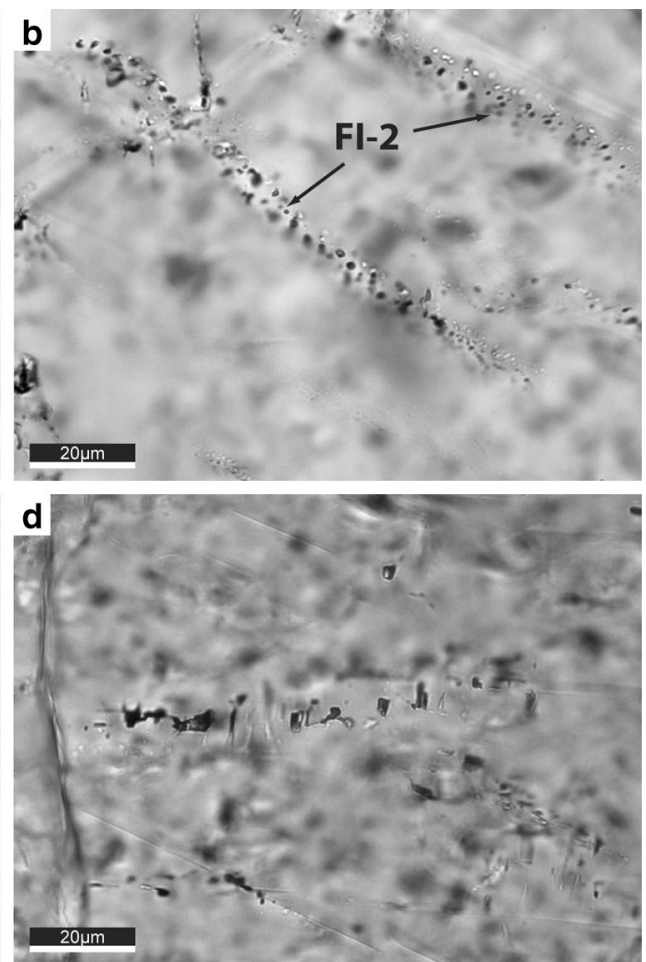

phases fluid inclusions occurring in little trails. c Secondary microcracks intersecting grain boundaries and containing little $(<5 \mu \mathrm{m})$ liquid mono-phase fluid inclusions. d Typical liquid mono-phase necking-down

\subsection{Composition of quartz and calcite in veins $(O$, C)}

The $\delta^{18} \mathrm{O}$ values of quartz (Table 1 ) have a range from +22.8 to $+26.3 \%$ (mean value at $+24.1 \%$ ) whereas the $\delta^{18} \mathrm{O}$ values of calcite have a range from +20.7 to $+27.3 \%$ (mean value at $+24.7 \%$ ). On two samples where both minerals are present, the difference between $\delta^{18} \mathrm{O}$ values of quartz and calcite $\left(\Delta^{18} \mathrm{O}\right)$ is 1.8 and $2.1 \%$. This corresponds to an apparent temperature of equilibration between 180 and $210^{\circ} \mathrm{C}$ (using Zheng 1999) that is reasonable regarding the estimations of fluid entrapment temperatures between 175 and $310{ }^{\circ} \mathrm{C}$ (Fig. 8). The $\delta^{18} \mathrm{O}$ values of quartz and calcite in the veins from the basalt pebble are lower than in sedimentary rocks. The $\delta^{13} \mathrm{C}$ values obtained on the calcite veins range from -1.1 to $+2.0 \%$ (Table 1). Calcite associated with quartz in two samples display similar values of $-2.0 \%$ (SL1a) and $+1.3 \%$ (SL2i).

\subsection{Fluid inclusion compositions $(\mathrm{H}, \mathrm{O}, \mathrm{C})$}

The $\delta \mathrm{D}$ values of water contained in fluid inclusions range from $-24 \%$ (sample SL3b) to $-73 \%$ (sample SL2h; Table 2) regardless of the nature of the host mineral (quartz 

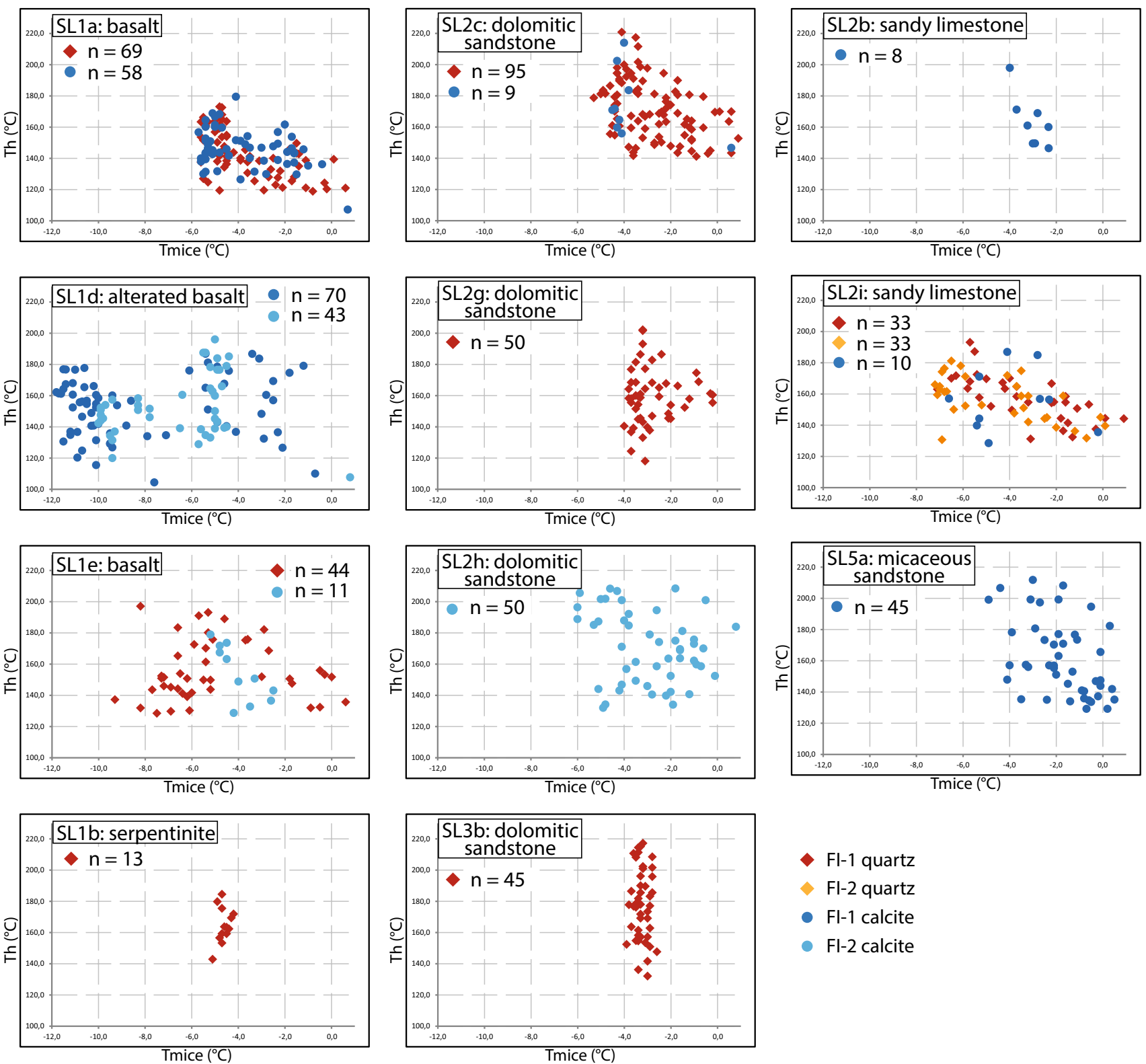

- Fl-1 quartz

Fl-2 quartz

- $\mathrm{Fl}-1$ calcite

- Fl-2 calcite

Fig. 7 Homogenization temperature (Th) versus melting ice temperature (Tmice) diagram from fluid inclusions studied in the various veins. $\mathrm{n}$ is the number of measures obtained on FI-1 and FI-2. All the graphs shown are from different samples. No significant difference can be noted between FI-1 and FI-2, as well as between quartz and calcite from the different samples. Only bimodality can be clearly distinguished in Tmice of SL1d and apparently in FI-1 of the quartz of SL1e, probably due to a post-trapping pebble alteration or calcite). In a given sample, the $\delta \mathrm{D}$ values obtained for the FI- 1 are always lower than the $\delta \mathrm{D}$ values for the FI-2 by about $20-30 \%$ (Table 2 ), largely higher than the analytical uncertainty.

The stable isotope compositions of minerals can be used to estimate that of the fluid in equilibrium with the mineral and hence help to identify its origin. The equilibrium fractionation between mineral species and fluids is dependent on the temperature of mineral precipitation. This temperature can be deduced from the intersection between isochores and the lithostatic gradient of $40{ }^{\circ} \mathrm{C} / \mathrm{km}$ (175-310 ${ }^{\circ} \mathrm{C}$; Fig. 8). At these temperatures, the calculated oxygen isotope compositions of the fluid $\left(\delta^{18} \mathrm{O}-\mathrm{H}_{2} \mathrm{O}\right.$; Table 2; Fig. 9) in equilibrium with quartz and with calcite range from +9.3 to $+16.2 \%$ at $175{ }^{\circ} \mathrm{C}$ and from +15.3 to $+21.9 \%$ at $310{ }^{\circ} \mathrm{C}$ respectively.

Using the fractionation factor from Ohmoto and Rye (1979), the calculated carbon isotope composition of the fluid in equilibrium with calcite at $175-310{ }^{\circ} \mathrm{C}$ ranges from -2.61 to $+4.15 \%$ (Table 2 ). 


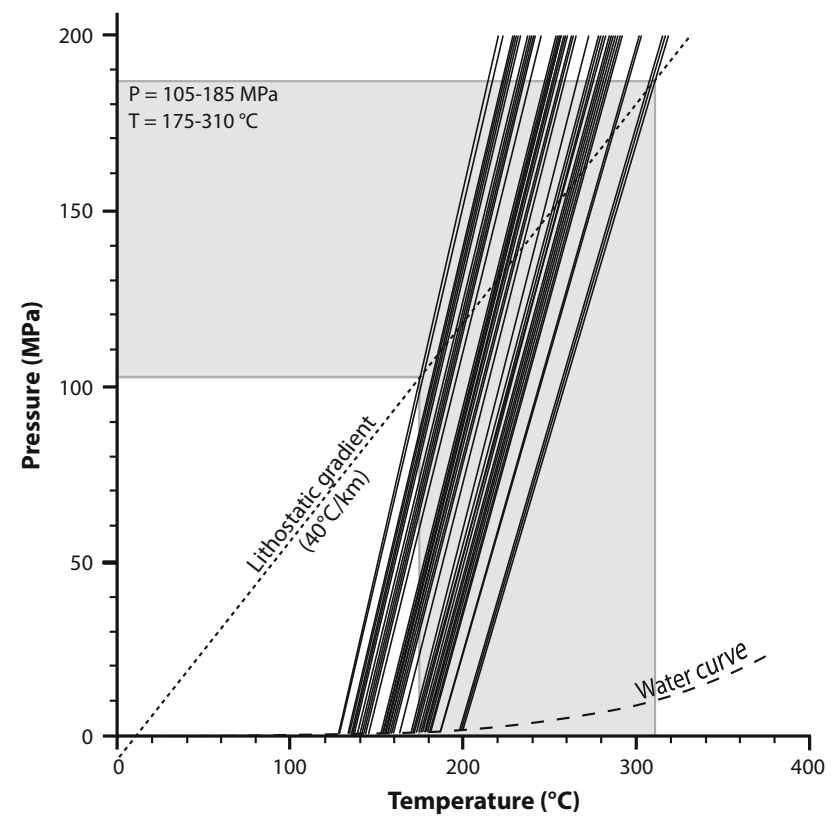

Fig. 8 P-T diagram showing the mean isochore for each studied sample. The P-T domain of fluid entrapment is given by the intersection of fluid inclusion isochores (standard deviation of microthermometric data) and the lithostatic gradient $(27 \mathrm{MPa} / \mathrm{km})$

\section{Discussion}

\subsection{Fluid source and fluid-rock interactions}

The fluid trapped in inclusions is $\mathrm{H}_{2} \mathrm{O}$-rich with small amounts of $\mathrm{CO}_{2}$. Tmice of fluid inclusions ( -6.5 to $-0.5^{\circ} \mathrm{C}$ ) indicate a low to moderate salinity from 0.9 to 9.8 wt $\%$ eq. $\mathrm{NaCl}$. This range of salinity might be explained by exchange of ions during the fluid transfer and its buffering by the carbonate series (Muchez et al. 1994; Dubois et al. 1996). In our set of data, the altered basalts SL1d and SL1e display bimodality in Tmice (Fig. 7) and where the high salinities likely origin in a local fluid circulation in these peculiar rocks.

Paired $\delta \mathrm{D}-\delta^{18} \mathrm{O}$ values for the majority of fluid inclusions (Fig. 9) indicate fluids of sedimentary or magmatic/ metamorphic origin, with no, or very limited, mixing with meteoric waters. This rather deep fluid can arise from migration of formation water during tectonic event or from the dehydration of the host rocks during prograde metamorphism.

The calculated $\delta^{18} \mathrm{O}$ values of fluid in equilibrium with quartz and calcite $(+9.3$ to $+21.9 \%)$ overlap with the $\delta^{18} \mathrm{O}$ values in quartz $(+9.3$ to $+20.8 \%$ ) and calcite $(+9.6$ to $+21.9 \%$ ) (Table 2 ). This variability of the $\delta^{18} \mathrm{O}$ values observed in minerals (quartz and calcite) and fluids could either be linked to the temperature of mineral precipitation or to the composition of the host rocks buffering the fluid composition.

The $\delta \mathrm{D}$ and $\delta^{18} \mathrm{O}$ values of the fluids and of the minerals in veins are lower in the basalt. These compositions can be correlated to the oxygen isotope composition of the basalt that is 3-6\% lower than sedimentary pebbles. The $\delta^{13} \mathrm{C}$ of the fluid (from -2.01 to $+2.05 \%$, Table 1 ) in equilibrium with calcite host mineral points to a marine sediment source.

Table $1 \delta^{18} \mathrm{O}$ and/or $\delta^{13} \mathrm{C}$ values obtained from the different whole rocks (pebbles) and their veins (quartz and calcite)

\begin{tabular}{|c|c|c|c|c|c|c|}
\hline \multirow[t]{2}{*}{ Sample } & \multicolumn{3}{|l|}{ Whole rock } & \multicolumn{3}{|l|}{ Vein } \\
\hline & Pebble petrology & $\begin{array}{l}\delta^{18} \mathrm{O}(\% \text { relative to } \\
\text { SMOW) }\end{array}$ & $\begin{array}{l}\delta^{13} \mathrm{C}(\% \text { relative to } \\
\mathrm{PDB})\end{array}$ & $\begin{array}{l}\text { Host } \\
\text { mineral }\end{array}$ & $\begin{array}{l}\delta^{18} \mathrm{O}(\% \text { relative to } \\
\text { SMOW) }\end{array}$ & $\begin{array}{l}\delta^{13} \mathrm{C} \text { (\%o relative to } \\
\mathrm{PDB})\end{array}$ \\
\hline \multirow[t]{2}{*}{ SL1a } & Basalt & 17 & & Qtz & 22.8 & \\
\hline & & & & Cal & 20.7 & -2.01 \\
\hline SL2b & Sandy limestone & 22.8 & -4 & $\mathrm{Cal}$ & 27.3 & -1.14 \\
\hline SL2c & Dolomitic sandstone & 20.6 & & Qtz & 23.3 & \\
\hline SL2g & Dolomitic sandstone & 22.4 & 1.2 & Qtz & 23.5 & \\
\hline SL2h & $\begin{array}{l}\text { Dolomitic sandy } \\
\text { limestone }\end{array}$ & 22.7 & & Cal & 25.7 & 2.05 \\
\hline \multirow[t]{2}{*}{ SL2i } & Sandy limestone & 24.3 & 1.4 & Qtz & 26.3 & \\
\hline & & & & Cal & 24.5 & 1.35 \\
\hline SL3b & Dolomitic sandstone & 21.5 & & Qtz & 24.7 & \\
\hline SL5a & Micaceous sandstone & 20 & & $\mathrm{Cal}$ & 25.3 & 1.69 \\
\hline SL3e & $\begin{array}{l}\text { Cement of } \\
\text { conglomerates }\end{array}$ & & & Cal & 20 & -1.7 \\
\hline Standard & Carrare & 29.14 & 2.1 & & & \\
\hline
\end{tabular}

The $\delta^{18} \mathrm{O}$ values have been measured on the silicate part of the whole rock and on quartz and calcite minerals of the veins, while the $\delta^{13} \mathrm{C}$ values have been measured on the carbonate fraction of the whole rocks (when possible) and on calcite minerals of the veins 
Table $2 \delta \mathrm{D}$ values obtained from FI-1 and FI-2, and calculated $\delta^{18} \mathrm{O}$ and/or $\delta^{13} \mathrm{C}$ values of the aqueous fluid at the equilibrium with the quartz and calcite minerals at 175 and $310^{\circ} \mathrm{C}$ (see Fig. 8 for the reconstructed isochores)

\begin{tabular}{|c|c|c|c|c|c|c|c|c|}
\hline \multicolumn{2}{|c|}{ Whole rocks } & \multirow{3}{*}{$\begin{array}{l}\text { Vein } \\
\text { Host mineral } \\
\text { Qtz }\end{array}$} & \multicolumn{6}{|c|}{ Fluid inclusion } \\
\hline \multirow{2}{*}{$\begin{array}{l}\text { Sample } \\
\text { SL1a }\end{array}$} & \multirow{2}{*}{$\begin{array}{l}\text { Pebble petrology } \\
\text { Basalt }\end{array}$} & & \multicolumn{2}{|c|}{$\overline{\delta D}(\%$ relative to SMOW) } & \multicolumn{2}{|c|}{$\delta^{18} \mathrm{O}(\%$ relative to SMOW) } & \multicolumn{2}{|c|}{$\delta^{13} \mathrm{C}$ (\%o relative to $\mathrm{PDB}$ ) } \\
\hline & & & -26.6 & & 9.3 & 17.3 & & \\
\hline & & $\mathrm{Cal}$ & & & 9.6 & 15.3 & -2.61 & -0.09 \\
\hline SL2b & Sandy limestone & $\mathrm{Cal}$ & & & 16.2 & 21.9 & -1.74 & 0.96 \\
\hline SL2c & Dolomitic sandstone & Qtz & -44.3 & & 9.8 & 17.8 & & \\
\hline SL2g & Dolomitic sandstone & Qtz & -60.2 & & 10.0 & 18.0 & & \\
\hline SL2h & Dolomitic sandy limestone & $\mathrm{Cal}$ & -73.3 & -44.6 & 14.6 & 20.3 & 1.45 & 4.15 \\
\hline \multirow[t]{2}{*}{ SL2i } & Sandy limestone & Qtz & & & 12.8 & 20.8 & & \\
\hline & & $\mathrm{Cal}$ & -35.9 & -28.7 & 13.4 & 19.1 & 0.75 & 3.45 \\
\hline SL3b & Dolomitic sandstone & Qtz & -47.2 & -24 & 11.2 & 19.2 & & \\
\hline \multirow[t]{2}{*}{ SL5a } & Micaceous sandstone & $\mathrm{Cal}$ & -50.4 & & 14.2 & 19.9 & 1.09 & 3.79 \\
\hline & & & FI-1 & FI-2 & $\mathrm{H}_{2} \mathrm{O}-175$ & $\mathrm{H}_{2} \mathrm{O}-310$ & $\mathrm{CO}_{2-175}$ & $\mathrm{CO}_{2}-310$ \\
\hline
\end{tabular}

The oxygen compositions are mean values after using different fractionation factors from Zheng (1993) and Méheut et al. (2007) for the $\mathrm{H}_{2} \mathrm{O}-\mathrm{Qz}$ equilibrium and from O'Neil et al. (1969), Zheng (1999) and Horita (2014) for the $\mathrm{H}_{2} \mathrm{O}-\mathrm{Ca}$ equilibrium. The carbon compositions are values calculated using the fractionation factor from Ohmoto and Rye (1979) for the $\mathrm{CO}_{2}-\mathrm{Ca}$ equilibrium

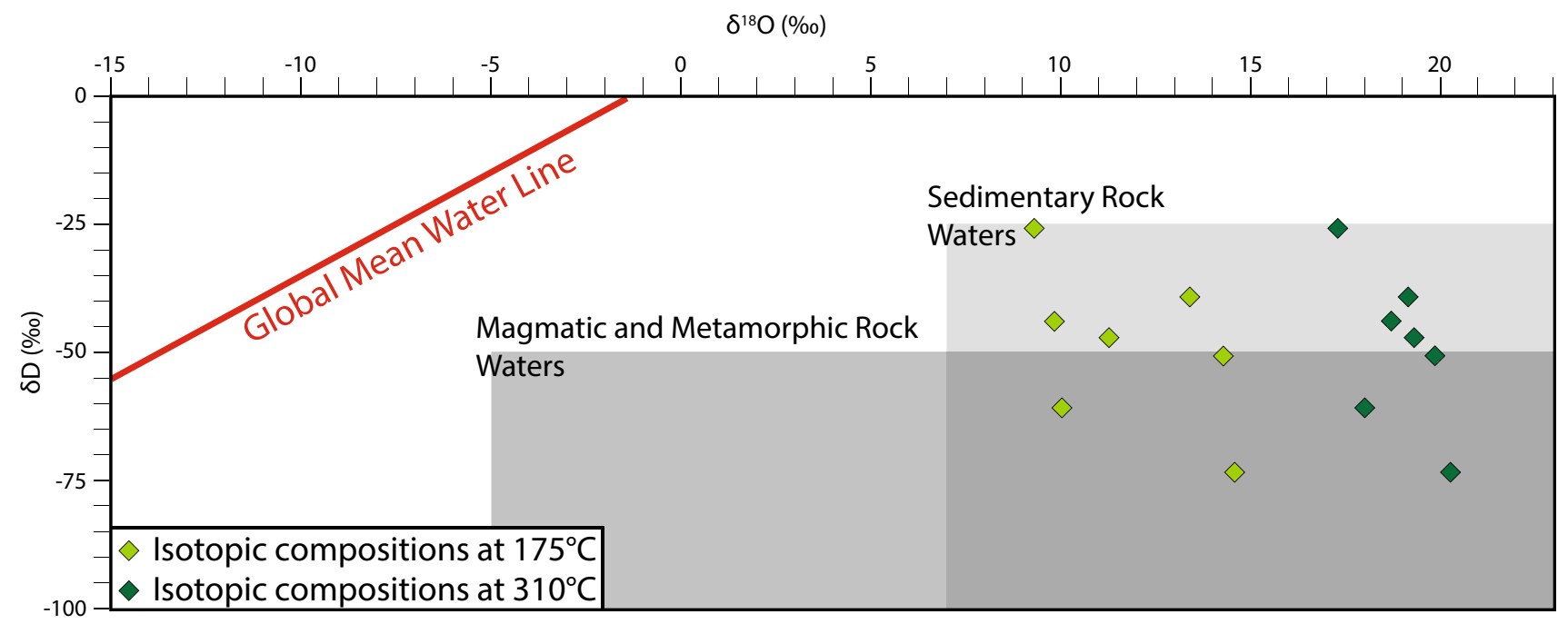

Fig. 9 Diagram showing the hydrogen and oxygen isotopic compositions of sedimentary rocks and magmatic/metamorphic rocks in the range of studied samples (modified from Hoefs 2009) (See Table 2 for $\delta \mathrm{D}$ and $\delta^{18} \mathrm{O}$ data). The Global Mean Water Line is also

The homogenous range of isotopic composition of fluids, minerals sealing veins and host rocks indicates that fluid compositions were buffered by the isotopic composition of the host rocks. This reflects dehydration of the host rocks and/or expulsion of formation water during metamorphism.

The calcite cement of the conglomerate (Fig. 2e) has likely crystallized in the foreland basin at the surface from meteoric water flow. The $\delta^{13} \mathrm{C}$ value of $-1.7 \%$ reflects high fluid/rock ratio by surficial water circulation in represented, summarizing the composition of meteoric waters. The obtained $\delta \mathrm{D}$ and $\delta^{18} \mathrm{O}$ values from the studied samples are plotted and indicate a deep origin of the fluid trapped in the veins during their crystallization

carbonate-rich Mesozoic series that surround the Barrême Basin and buffering of the water by marine carbonate rocks.

To conclude, the isotopic compositions of the veins within the pebbles are not compatible with the presence of meteoric water during their crystallization, thus preventing any relief elevation estimation (Sharp et al. 2005). However, the microthermometric data of deep fluids allowed the determination of $\mathrm{P}-\mathrm{T}$ conditions during the fluid trapping of $105-185 \mathrm{MPa}$ and $175-310^{\circ} \mathrm{C}$ (Fig. 8). Related 
pressures under lithostatic gradient correspond to depths of 4-7 km for vein formation (lithostatic gradient is based on $27 \mathrm{MPa} / \mathrm{km}$; Fig. 8). Such depth of fluid trapping is consistent with the estimation of nappe thickness along and to the west of (Embrun-Ubaye Nappe) the Pennine Thrust Front at around $8-10 \mathrm{~km}$ and $6-8 \mathrm{~km}$ respectively (Labaume et al. 2008).

\subsection{Drainage pathway from source to sink}

Petrological and geochemical studies of the St-Lions Conglomerates allow the determination of the provenance of the majority of the pebbles. Radiolarites associated with serpentinites, basalts and blueschist pebbles originate from the internal zones of the Western Alps (Cordey et al. 2012; Jourdan et al. 2012; Schwartz et al. 2012), while the source of the micaceous sandstones is in a more external part of the Alps, the Embrun-Ubaye Nappe (Kerkhove 1969; Figs. 1, 10). By contrast, the sedimentary pebbles (Triassic, Jurassic, Cretaceous and Eocene), that are dominant in the conglomerate (Fig. 2d), are classically interpreted as coming from local topographic highs bordering the basin (Gubler 1958; Chauveau and Lemoine 1961; Bodelle 1971). However, the provenance of Liassic limestones and Triassic sandstones/limestones was not yet clear since these facies are present in the Briançonnais Zone (Internal Alps) and also at the base of the Provençal Nappe (Figs. 1, 10).

The mineralogy of the vein fillings can help us to better constrain the source of the pebbles. Chlorite-epidote assemblages are frequent in veins of the studied set of pebbles. This assemblage is not observed in the sandstones and limestones that form the modern-day topographic highs around the Barrême Basin. Also they are not observed in the pebbles resulting from the erosion of the local topographies (e.g. Nummulitic limestones). Thus, we conclude that most of the sedimentary pebbles (SL2b, SL2c, SL2g, SL2h, SL3b and SL2i) cannot be derived from the erosion of the reliefs surrounding the basin but have a source that is likely to be a more internal area having recorded fracturing. The microthermometric data corroborate that micaceous sandstones, serpentinites and basalts record similar $\mathrm{P}-\mathrm{T}$ evolutions. These observations suggest that vein formation in all these samples occurred under very close pressure and temperature conditions, so approximately at the same depth in the crust.

In the Barrême Basin, the St-Lions Conglomerates are overlain by continental molassic deposits (Red Molasses, Grey Series and Green Sandstones; Fig. 2a) that do not exceed $480 \mathrm{~m}$ of thickness (de Graciansky et al. 1982). Such thickness is not compatible with the pressure conditions recorded by the rocks that give a depth of 4-7 km upon the opening of the veins. The east of the Pennine Thrust Front, a boundary between the Piemontais and the

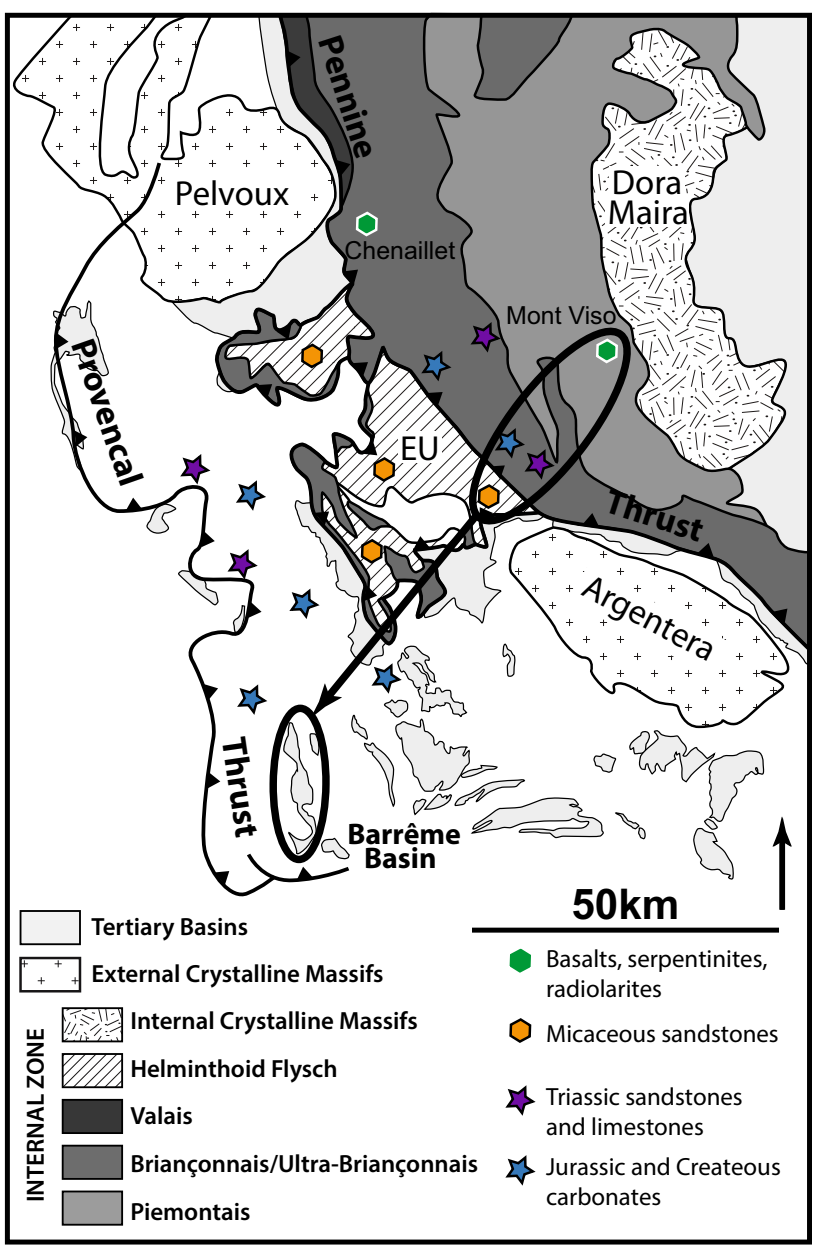

Fig. 10 Location of the potential source areas (in the Internal Alps and in the foreland basin) of the pebble lithologies analyzed in this study. Petrographic and homogeneous microthermometric data suggest the vein cementation in the Western Alps implying the location of the catchment area of the pebble dataset in the Briançonnais and Piemontais massifs. EU Embrun-Ubaye nappe

Briançonnais zones, combines rocks of oceanic crust and sedimentary rocks of the European passive margin (Lemoine and Tricart 1986; Tricart and Schwartz 2006; de Graciansky et al. 2011). We propose that this zone is the source area of the St-Lions Conglomerates pebbles (Fig. 10). Furthermore, the well-known location of each lithology in the Western Alps, allows the identification of the drainage pathway from the Piemontais Zone (source) to the Barrême Basin (sink), across the Briançonnais Zone and the Embrun-Ubaye Nappe (Fig. 10).

\subsection{Regional tectonic and topographic implications}

The metamorphic gradient of the Western Alps increases from the western external arc to the eastern internal arc. The External Crystalline Massifs and the Briançonnais Zone record greenschist facies conditions (Goffé et al. 2004 and reference therein), while the Piemontais Zone has 
a gradient from blueschist to eclogitic facies as well as the Internal Crystalline Massifs (Schwartz et al. 2000; Tricart and Schwartz 2006; Bousquet et al. 2008). The absence of high-grade metamorphic minerals in veins crosscutting the basalts and the presence of serpentinite pebbles coming from the Piemontais Zone (Schwartz et al. 2012) suggest that these rocks have been fractured and cemented at shallow depth of the continental crust after the high-grade metamorphism. The oceanic accretionary prism emerges during the Lower Oligocene (34-30 Ma; Morag et al. 2008; Bernet and Tricart 2011), synchronous with the emplacement of the Embrun-Ubaye Nappe (32-30 Ma; Ford et al. 2006; Simon-Labric et al. 2009). The detrital sediments from these massifs constitute part of the StLions Conglomerates (serpentinite and blueschist pebbles) which were deposited between 30 and $28 \mathrm{Ma}$ (Fig. 2a). Thus, we conclude that the formation of the veins is coeval with the exhumation of the Internal Crystalline Massif that occurred at about 32-30 Ma, before their erosion and the Oligocene sedimentation in the basin. The link between vein formation and tectonic event is in agreement with the structures of deformation observed at the mineral scale (Fig. 5), with the presence of low-grade metamorphic minerals (chlorite and epidote) in the veins (Fig. 3f), and finally with the fluid inclusion conditions of formation (Fig. 8).

The similar trapping conditions of the fluids within their host minerals suggest fluid/rock interactions and/or rock dehydration over a regional scale. This feedback corresponds to a regional tectonic event that fractured the rocks from the Piemontais Zone to the Embrun-Ubaye Nappe. This is consistent with a short-lived, fast erosional exhumation $(1.5-2 \mathrm{~km} / \mathrm{Ma})$ between 30 and $28 \mathrm{Ma}$ as proposed by Jourdan et al. (2013). This exhumation event is also recorded by comparable microthermometric data between FI-1 and FI-2 in samples (SL1d and SL2i in Fig. 7) recording that the two populations have formed under comparable conditions during a short time span. In response to this uplift, a regional drainage system eroded part of 4-7 km of rocks and redistributed detrital material along a profile from the highest topographies in the Piemontais Zone (source) to the foreland basin (sink). This proposed evolution agrees with the maintenance of the general Western Alps topography since the Oligocene, as the higher topographies are still located in the Piemontais and Briançonnais zones (Fauquette et al. 2015).

\section{Conclusions}

Classically, provenance studies are based on the application of petrographic and geochemical techniques on whole rocks or minerals (for review see Najman 2006). In this study, we also used such classical petrologic-petrographic methods but have added a new approach based on the fluid inclusions and stable isotope compositions of vein minerals within different pebbles of the sedimentary rocks. This approach can further refine our interpretations on the provenance and hence regional geology of the Alps.

Our data illustrate that all quartz-calcite veins crosscutting the studied pebbles contain a fluid trapped at about 175-310 ${ }^{\circ} \mathrm{C}$ and $105-185 \mathrm{MPa}$, under about $4-7 \mathrm{~km}$ of rocks. While the endogenous pebbles have been sourced in the internal massifs of the Western Alps, the provenance of sedimentary pebbles was still poorly constrained. The same entrapment conditions recorded by all magmatic, metamorphic and sedimentary clasts have allowed for a distinction between the sedimentary pebbles resulting from the erosion of the orogenic wedge from those sourcing in local topographic highs. Knowing the location of sedimentary cover in the Western Alps, the drainage pathway through the different massifs of the orogenic wedge can be reconstructed from source to sink. Moreover, the similar isotopic composition in oxygen and carbon of the fluid and of host rocks is consistent with the buffering of water during percolation through the rocks and/or with the expulsion of formation water during low grade metamorphism. Finally, the homogenous fluid composition and depth of fluid trapping argue for vein crystallization during a unique tectonic event. Thus, we conclude that the formation of these veins coincides with the major Early Oligocene tectonic event that induced the rapid Western Alps exhumation, their subsequent erosion and the mass redistribution in the foreland basin.

Acknowledgments This study was carried out within the framework of the project ANR-08-BLANC-0303-01 "Erosion and Relief Development in the Western Alps" financially supported by the Agence National de la Recherche. The paper benefited from the reviews of Dr. A. Richard and Pr. J. Mullis, and from the editorial work of Pr. W. Winkler.

\section{References}

Bernet, M., Brandon, M., Garver, J., Balestieri, M. L., Ventura, B., \& Zattin, M. (2009). Exhuming the Alps through time: clues from detrital zircon fission-track thermochronology. Basin Research, 21, 781-798.

Bernet, M., \& Tricart, P. (2011). The Oligocene orogenic pulse in the southern Penninic arc (western Alps): Structural, sedimentary and thermochonological contraints. Bulletin de la Société Geologique de France, 182, 25-36.

Bodelle, J. (1971). Les Formations Nummulitiques de l'Arc de Castellane, Ph.D. dissertation, University of Nice, France, pp. 540.

Bodnar, R. J. (1993). Revised equation and table for determining the freezing point depression of $\mathrm{H}_{2} \mathrm{O}-\mathrm{NaCl}$ solutions. Geochimica Cosmochimica Acta, 57, 683-684. 
Böhlke, J. K., Alt, J. C., \& Muehlenbachs, K. (1984). Oxygen isotope-water relations in altered deep-sea basalts: Low-temperature mineralogical controls. Canadian Journal of Earth Sciences, 21, 67-77.

Bousquet, R., Oberhänsli, R., Goffé, B., Wiederkeht, M., Koller, F., Schmid, S. M., et al. (2008). Metamorphism of metasediments at the scale of an orogen: A key to the Tertiary geodynamic evolution of the Alps. In S. Siegesmund, B. Fügenschuh, \& N. Froitzheim (Eds.), Tectonic aspects of the Alpine-dinaridecarpathian system (Vol. 298, pp. 393-411). London: Geological Society Special Publication.

Browne, P. R. L. (1978). Hydrothermal alteration in active geothermal fields. Annual Review of Earth and Planetary Sciences, 6, 229-250.

Burbank, D. W. (2002). Rates of erosion and their implications for exhumation. Mineralogical Magazine, 66, 25-52.

Černý, P., \& Chapman, R. (1986). Adularia from hydrothermal vein deposits: Extremes in structural state. Canadian Mineralogist, 24, 717-728.

Chauveau, J. C., \& Lemoine, M. (1961). Contribution à l'étude géologique du synclinal tertiaire de Barrême (moitié nord). Bulletin du Service Carte Géologique de la France, 58, 147-178.

Clayton, R. N., \& Mayeda, T. K. (1963). The use of bromine pentafluoride in the extraction of oxygen from oxides and silicates for isotopic analysis. Geochimica Cosmochimica Acta, $27,43-52$.

Cordey, F., Tricart, P., Guillot, S., \& Schwartz, S. (2012). Dating the Tethyan ocean in the Western Alps with radiolarite pebbles from synorogenic Oligocene molasses basins (southeast France). Swiss Journal of Geosciences, 105, 39-48.

Coward, M. P., \& Dietrich, D. (1989). Alpine tectonics: An overview. In M. P. Coward, D. Dietrich, \& R. G. Park (Eds.), Alpine tectonics (Vol. 45, pp. 1-29). London: Geological Society Special Publication.

Craig, H. (1961). Isotopic variations in meteoric waters. Science, 133, 1702-1703.

de Graciansky, P. C., Dardeau, G., Lemoine, M., \& Tricart, P. (1989). The inverted margin of the French Alps and foreland inversion. In M. A. Cooper \& G. D. Williams (Eds.), Inversion tectonics (Vol. 44, pp. 97-104). London: Geological Society Special Publication.

de Graciansky, P. C., Durozoy, G., \& Gigot, P. (1982). Notice explicative de la feuille de Digne à 1:50000. Orléans: Bureau de Recherches Géologiques et Minières.

de Graciansky, P.C., Roberts, D.G., \& Tricart, P. (2011) The Western Alps, from Rift to Passive Margin to Orogenic Belt, an integrated geoscience overview. In J.F. Schroder Jr (Ed.) Development in Earth Surface Processes (Vol. 14, 388 pp.). Amsterdam: Elsevier.

DeCelles, P. G., \& Giles, K. A. (1996). Foreland basin systems. Basin Research, 8, 105-123.

Dewey, F. D., Pitman, W. C., Ryan, W. B. F., \& Bonnin, J. (1973). Plate tectonics and the evolution of the Alpine system. Geological Society of America Bulletin, 84, 3137-3180.

Dubois, M., Ayt Ougoudal, M., Meere, P., Royer, J. J., Boiron, M. C., \& Cathelineau, M. (1996). Temperature of paleo- to modern selfsealing within a continental rift basin: The fluid inclusion data (Soultz-sous-Forêt, Rhine graben, France). European Journal of Mineralogy, 8, 1065-1080.

Dumont, T., Simon-Labric, T., Authemayou, C., \& Heymes, T. (2011). Lateral termination of the north-directed Alpine orogeny and the onset of westward escape in the Western Alpine arc: Structural and sedimentary evidence from the external zone. Tectonics, doi:10.1029/2010TC002836.

Fauquette, S., Bernet, M., Suc, J.-P., Grosjean, A.-S., Guillot, S., Van der Beek, P., et al. (2015). Quantifying the Eocene to Pleistocene topographic evolution of the southwestern Alp, France and Italy. Earth and Planetary Science Letters, 412, 220-234.

Folk, R. L. (1965). Some aspects of recrystallization in ancient limestones. In L. C. Pray \& R. C. Murray (Eds.), Dolomitization and limestone diagenesis: A symposium (Vol. 13, pp. 14-48). Tulsa: The Society of Economic Paleontologists and Mineralogists Special Publications.

Ford, M., Duchêne, S., Gasquet, D., \& Vanderhaeghe, O. (2006). Two-phase orogenic convergence in the external and internal SW Alps. Journal of the Geological Society, 163, 815-826.

Ford, M., \& Lickorish, W. H. (2004). Foreland basin evolution around the western Alpine arc. In P. Joseph \& S. A. Lomas (Eds.), Deepwater sedimentation in the Alpine basin of SE France: New perspectives on the Grès d'Annot and related systems (Vol. 221, pp. 39-63). London: Geological Society Special Publication.

Friedman, I. (1953). Deuterium content of natural waters and other substances. Geochimica Cosmochimica Acta, 4, 89-103.

Gébelin, A., Mulch, A., Teyssier, C., Jessup, M. J., Law, R. D., \& Brunel, M. (2013). The Miocene elevation of Mount Everest. Geology, 41, 799-802.

Goffé, B., Schwartz, S., Lardeaux, J. M., \& Bousquet, R. (2004). Explanatory Notes to the Map: Metamorphic structure of the Alps Western and Ligurian Alps. Mitteilungen Österreichische Mineralogischen Gesellschaft, 149, 125-144.

Goldstein, R. H. (2001). Fluid inclusions in sedimentary and diagenetic systems. Lithos, 55, 159-193.

Grosjean, A.-S., Pittet, B., Ferry, S., Mahéo, G., \& Gardien, V. (2012). Reconstruction of Tertiary palaeovalleys in the South Alpine Foreland Basin of France (Eocene-Oligocene of the Castellane arc). Sedimentary Geology, 275-276, 1-21.

Grosjean, A.-S., Pittet, B., Gardien, V., Leloup, P.-H., Mahéo, G., \& Barraza-Garcia, J. (2015). Tectonic heritage in drainage pattern and dynamics: the case of the French South Alpine Foreland Basin (ca. 45-20 Ma). Basin Research,. doi:10.1111/bre.12134.

Gubler, Y. (1958). Étude critique des sources du matériel constituant certaines séries détritiques dans le tertiaire des Alpes françaises du sud: formations détritiques de Barrême, flysch Grès d'Annot. Eclogae Geologicae Helvetiae, 51, 942-977.

Handy, M. R., Schmid, S. M., Bousquet, R., Kissling, E., \& Bernoulli, D. (2010). Reconciling plate-tectonic reconstructions of Alpine Tethys with the geological-geophysical record spreading and subduction in the Alps. Earth-Science Reviews, 102, 121-158.

Hoefs, J. (2009). Stable isotope geochemistry (p. 286). Berlin: Springer.

Horita, J. (2014). Oxygen and carbon isotope fractionation in the system dolomite-water- $\mathrm{CO}_{2}$ to elevated temperatures. Geochimica Cosmochimica Acta, 129, 111-124.

Jourdan, S., Bernet, M., Schwartz, S., Guillot, S., Tricart, P., Chauvel, C., et al. (2012). Tracing the oligocene-miocene evolution of the Western Alps drainage divide with Pebble petrology, geochemistry, and Raman spectroscopy of Foreland basin deposits. Journal of Geology, 120, 603-624.

Jourdan, S., Bernet, M., Tricart, P., Hardwick, E., Paquette, J. L., Guillot, S., et al. (2013). Short-lived, fast erosional exhumation of the internal western Alps during the late early Oligocene: Constraints from geothermochronology of pro- and retro-side foreland basin sediments. Lithosphere, 5, 211-225.

Kerkhove, C. (1969). La "zone du Flysch" dans les nappes de l'Embrun-Ubaye (Alpes occidentales). Géologie Alpine, 45, 5-204.

Krenn, K., Bauer, C., Proyer, A., Mposkos, E., \& Hoinkes, G. (2008). Fluid entrapment and reequilibration during subduction and exhumation: A case study from the high-grade Nestos shear zone, Central Rhodope, Greece. Lithos, 104, 33-53.

Kyser, T. K. (1986). Stable isotope variations in the mantle. Reviews in Mineralogy and Geochemistry, 16, 141-164. 
Labaume, P., Jolivet, M., Souquière, F., \& Chauvet, A. (2008). Tectonic control on diagenesis in foreland basin: Combined petrologic and thermochronologic approaches in the Grès d'Annot basin (Late Eocene-Earli Oligocene, French-Italian external Alps). Terra Nova, 20, 95-101.

Lanari, P., Guillot, S., Schwartz, S., Vidal, O., Tricart, P., Riel, N., et al. (2011). Diachronous evolution of the alpine continental subduction wedge: Evidence from $\mathrm{P}-\mathrm{T}$ estimates in the Briançonnais Zone houillère (France - Western Alps). Journal of Geodynamics, 56-57, 39-54.

Lemoine, M., \& Tricart, P. (1986). Les schistes lustrés piémontais dans les Alpes Occidentales: Approche stratigraphique, structurale et sédimentologique. Eclogae Geologicae Helvetiae, 79, 271-294.

Marsala, A., Wagner, T., \& Wälle, M. (2013). Late-metamorphic veins record deep ingression of meteoric water: A LA-ICPMS fluid inclusion study from the fold-and-thrust belt of the Rhenish Massif, Germany. Chemical Geology, 351, 134-153.

Méheut, M., Lazzeri, M., Balan, E., \& Mauri, F. (2007). Equilibrium isotopic fractionation in the kaolinite, quartz, water system: Prediction from first-principles density-functional theory. Geochimica Cosmochimica Acta, 71, 3170-3181.

Miron, G. D., Wagner, T., Wälle, M., \& Heinrich, C. A. (2013). Major and trace-element composition and pressure-temperature evolution of rock-buffered fluids in low-grade accretionary-wedge metasediments, Central Alps. Contribution to Mineralogy and Petrology, 165, 981-1008.

Morag, N., Avigad, D., Harlavan, Y., McWilliams, M. O., \& Michard, A. (2008). Rapid exhumation and mountain building in the Western Alps: Petrology and ${ }^{40} \mathrm{Ar} /{ }^{39} \mathrm{Ar}$ geochronology of detritus from Tertiary basins of southeastern France. Tectonics, . doi:10.1029/2007TC002142.

Muchez, P., Marshall, J. D., Touret, J. L. R., \& Viaene, W. A. (1994). Origin and migration of palaeofluids in the Upper Visean of the Campine Basin, Northern Belgium. Sedimentology, 41, 133-145.

Muehlenbachs, K., \& Clayton, R. N. (1972). Oxygen isotope studies of fresh and weathered submarine basalts. Canadian Journal of Earth Sciences, 9, 172-184.

Mullis, J. (1994). P-T-t path of quartz formation in extensional veins of the Central Alps. Schweizerische Mineralogische und Petrographische Mitteilungen, 76, 159-164.

Najman, Y. (2006). The detrital record of orogenesis: A review of approaches and techniques used in the Himalayan sedimentary basins. Earth-Science Reviews, 74, 1-72.

O’Neil, J. R., Clayton, R. N., \& Mayeda, T. K. (1969). Oxygen isotope fractionation in divalent metal carbonates. Journal of Chemical Physics, 51, 5547-5558.

Ohmoto, H., \& Rye, R. O. (1979). Isotope of sulfure and carbon. In H. L. Barnes (Ed.), Geochemistry of hydrothermal ore deposits (2nd ed., pp. 509-561). New York: Wiley.

Roedder, E. (1984). Fluid inclusions. In P.H. Ribbe (Ed) Reviews in Mineralogy (Vol. 12, p. 644). Washington: Mineralogical Society of America.

Rosenbaum, G., \& Lister, G. S. (2005). The Western Alps from the Jurassic to Oligocene: Spatio-temporal constraints and evolutionary reconstructions. Earth-Science Reviews, 69, 281-306.
Schimd, S. M., \& Kissling, E. (2000). The arc of the western Alps in the light of geophysical data on deep crustal structure. Tectonics, $19,62-85$.

Schwartz, S., Guillot, S., Tricart, P., Bernet, M., Jourdan, S., Dumont, T., et al. (2012). Source tracing of detrital serpentinite in the Oligocene molasse deposits from the western Alps (Barrême basin): Implications for relief formation in the internal zone. Geological Magazine, 149, 841-856.

Schwartz, S., Lardeaux, J. M., Guillot, S., \& Tricart, P. (2000). The diversity of eclogitic metamorphism in the Monviso Ophiolitic Complex, western Alps, Italy. Geodynamica Acta, 13, 169-188.

Sharp, Z. D., Masson, H., \& Licchini, R. (2005). Stable isotope geochemistry and formation mechanisms of quartz veins; extreme paleoaltitudes of the Central Alps in the Neogene. American Journal of Science, 305, 187-219.

Siddans, A. W. B. (1979). Arcuate fold and thrust pattern in the subalpine chains of southeast France. Journal of Structural Geology, 1, 117-126.

Siebenaller, L., Boiron, M. C., Vanderhaeghe, O., Hibsch, C., Jessel, M. W., Andre-Mayer, A. S., et al. (2012). Fluid record of rock exhumation across the brittle-ductile transition during formation of a Metamorphic Core Complex (Naxos Island, Cyclades, Greece). Journal of Metamorphic Geology, 31, 313-328.

Simon-Labric, T., Rolland, Y., Dumont, T., Authemayou, C., Corsini, M., \& Forani, M. (2009). ${ }^{40} \mathrm{Ar} /{ }^{39} \mathrm{Ar}$ dating of Penninic Front tectonic displacement (W Alps) during the Lower Oligocene (31-34 Ma). Terra Nova, 21, 127-136.

Spötl, C., \& Vennemann, T. W. (2003). Continuous-flow isotope ratio mass spectrometric analysis of carbonate minerals. Rapid Commununications in Mass Spectrometry, 17, 1004-1006.

Tricart, P., \& Schwartz, S. (2006). A north-south section across the Queyras Schistes Lustrés (Piedmont zone, western Alps): Syncollision refolding of a subduction wedge. Eclogae Geologicae Helvetiae, 99, 429-442.

Van den Kerkhof, A. M., \& Hein, U. F. (2001). Fluid inclusion petrography. Lithos, 55, 27-47.

Vennemann, T. W., \& O’Neil, J. R. (1993). A simple inexpensive method of hydrogen isotope and water analysis of minerals and rocks based on zinc reagent. Chemical Geology, 103, 227-234.

von Eynatten, H. (2003). Petrography and chemistry of sandstones from the Swiss Molasse Basin: An archive of the Oligocene to Miocene evolution of the Central Alps. Sedimentology, 50, 703-724.

Zhang, Y. G., \& Frantz, J. D. (1987). Determination of the homogenization temperatures and densities of supercritical fluids in the system $\mathrm{NaCl}-\mathrm{KCl}-\mathrm{CaCl}_{2}-\mathrm{H}_{2} \mathrm{O}$ using synthetic fluid inclusions. Chemical Geology, 64, 335-350.

Zheng, Y. F. (1993). Calculation of oxygen isotope fractionation in anhydrous silicate minerals. Geochimica Cosmochimica Acta, 57, 1079-1091.

Zheng, Y. F. (1999). Oxygen isotope fractionation in carbonate and sulphate minerals. Geochemical Journal, 33, 109-126. 